\title{
Ring-opening reaction of 2,5-dioctyl- dithieno[2,3-b:3',2'-d]thiophene in the presence of aryllithium reagents
}

\author{
Hao Zhong ${ }^{1}$, Jianwu Shi ${ }^{1}$, Jianxun Kang ${ }^{2}$, Shaomin Wang ${ }^{2}$, Xinming Liu ${ }^{1}$ \\ and Hua Wang ${ }^{* 1}$
}

\section{Full Research Paper}

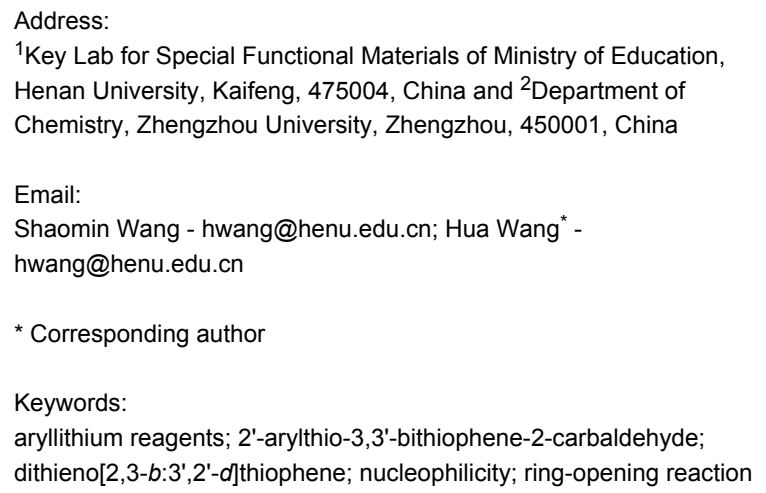

${ }^{1}$ Key Lab for Special Functional Materials of Ministry of Education, Henan University, Kaifeng, 475004, China and ${ }^{2}$ Department of Chemistry, Zhengzhou University, Zhengzhou, 450001, China

\author{
Beilstein J. Org. Chem. 2013, 9, 767-774. \\ doi:10.3762/bjoc.9.87 \\ Received: 12 January 2013 \\ Accepted: 29 March 2013 \\ Published: 19 April 2013 \\ Associate Editor: T. P. Yoon \\ () 2013 Zhong et al; licensee Beilstein-Institut. \\ License and terms: see end of document.
}

\begin{abstract}
In this paper, the ring-opening reaction of 2,5-dioctyldithieno[2,3-b:3', $\left.2^{\prime}-d\right]$ thiophene with aryllithium in THF at low temperature to generate 2'-arylthio-3,3'-bithiophene-2-carbaldehydes is studied. Nine examples are explored and all the products are characterized by ${ }^{1} \mathrm{H}$ NMR, ${ }^{13} \mathrm{C}$ NMR and HRMS. The relative relationship between the structures of aryl groups and the efficiency of ringopening reactions are discussed.
\end{abstract}

\section{Introduction}

Due to the promising optical and electrical properties, the derivatives of dithieno[2,3-b:3',2'-d] thiophene (DTT), as one type of fused oligothiophene, have shown their potential applications in organic electronics [1-4]. The work on the synthesis of DTT derivatives and the chemical stability of the DTT core is of particular interest. To construct DTT functional materials, deprotonation of DTT with organolithium reagents seems to be one of the most important approaches. However, the ringopening reaction of DTT leading to the cleavage of the center ring can be observed in the presence of $n$-BuLi. In our previous work, we reported the synthesis of a series of symmetric substituted dithieno[2,3-b:3',2'- $d]$ thiophenes and their ring-opening reactions in the presence of $n$-BuLi. The 3,3'-bithiophene-2carbaldehydes were generated after quenching with an electrophile, i.e., dry DMF (Scheme 1) [5].

The uncommon ring opening of fused thiophene derivatives in the presence of $n$-BuLi, though it has been reported, does not draw as much attention as the ring opening of other heterocyclic compounds [6-9]. The limited number of reports include 


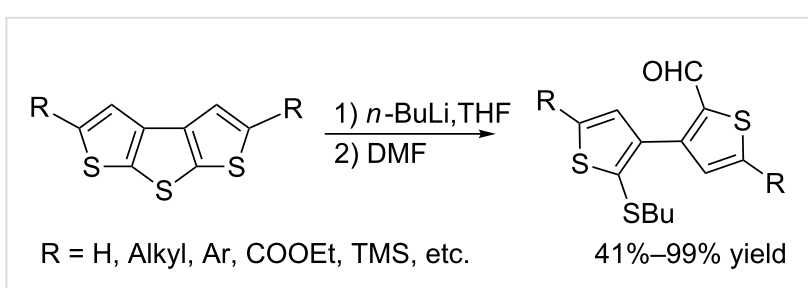

Scheme 1: The ring-opening reaction of symmetric 2,5-disubstituteddithieno[2,3-b:3',2'-d]thiophenes in the presence of $n$-BuLi in THF.

derivatives of benzo[ $b]$ thiophene [10-12], thieno[3,2- $d]$ thiazole $[10,11]$, and thieno[3,2- $b]$ thiophene [13]. More recently, Nenajdenko et al. reported that fused thieno[2,3- $b]$ thiophenes and some $[3,2-b]$-fused oligothiophenes were attacked by organolithium reagents resulting in the cleavage of thiophene rings [14]. They found when competitive deprotonation of the substrate was possible, high selectivity towards the ring opening was observed with $n$-BuLi when compared with other organolithium reagents. However, most of these ring-opening reactions mentioned above take place by using $n$-BuLi as the nucleophile to attack the sulfur atoms of thiophenes. Other organolithium reagents have rarely been employed for this kind of reaction. Furthermore, the relationship between the nucleophilicity of organolithium reagents and the efficiency of the ring opening of fused thiophenes has not been discussed.

In this paper, we present the ring opening of 2,5dioctyldithieno[2,3-b:3',2'-d] thiophene (1) with nine aryllithium reagents and the characterization of the nine corresponding ring-opening products. These studies should facilitate the understanding of the chemical stability of dithieno[2,3$\left.b: 3^{\prime}, 2^{\prime}-d\right]$ thiophene, which may be of importance in both organic chemistry and materials science. Furthermore, we show a novel method for the synthesis of 2'-arylthio-3,3'-bithiophene-2carbaldehydes based on the ring-opening reaction.

\section{Results and Discussion Ring-opening reaction of 2,5-dioctyl- dithieno[2,3-b:3',2'-d]thiophene in the pres- ence of aryllithium reagents}

The aryllithium reagents $(\mathrm{Ar}-\mathrm{Li})$ were obtained from the metal-halogen exchange of $\mathrm{Ar}-\mathrm{Br}$ and $n$-BuLi. To avoid the possible influence from excess $n$-BuLi, 1.4 equiv $\mathrm{Ar}-\mathrm{Br}$ was treated with 1.3 equiv $n$-BuLi at $-78{ }^{\circ} \mathrm{C}$ for $2 \mathrm{~h}$ to make sure that only excess $\mathrm{Ar}-\mathrm{Li}$ (1.3 equiv) was employed for the ringopening reaction. Then a solution of 1 was added at $-78{ }^{\circ} \mathrm{C}$, at which point the reaction mixture was slowly warmed to $-30{ }^{\circ} \mathrm{C}$ for $3 \mathrm{~h}$. After quenching with dry DMF, the corresponding ringopening products 2'-arylthio-3,3'-bithiophene-2-carbaldehydes were obtained.
Nine aryllithium reagents were employed for the ring-opening reaction of $\mathbf{1}$ as shown in Table 1. The molecular structures and the effects of electron-donating groups (EDG) and electronwithdrawing groups (EWG) of the aryllithium reagents were studied. Compared to the compound $\mathbf{2 d}$ (Table 1, entry 4) bearing EWG groups, the compounds $\mathbf{2 b}, \mathbf{2 c}$ and $\mathbf{2 e}$ (Table 1, entries 2, 3 and 5), all of which have EDG groups, generated higher yields of products, namely $73 \%$ (3b), $74 \%$ (3c) and $83 \%$ (3e), respectively. In the case of $\mathbf{2 b}$, not only was $\mathbf{3 b}$ obtained, but also a byproduct with similar polarity, 2'-butylsulfanyl-5,5'dioctyl-[3,3'-bithiophene]-2-carbaldehyde [5], was generated when the metal-halogen exchange temperature was set to $-78{ }^{\circ} \mathrm{C}$. If the reaction temperature of the metal-halogen exchange was set to $-78{ }^{\circ} \mathrm{C}$ first, and then warmed up to $-30{ }^{\circ} \mathrm{C}$ for $3 \mathrm{~h}$, only $\mathbf{3 b}$ could be generated in $70 \%$ yield (Table 1 , entry 3 ). The byproduct formed in the case of $\mathbf{2} \mathbf{b}$ implies that the metal-halogen exchange cannot be completed at $-78{ }^{\circ} \mathrm{C}$.

Similar to the case of $2 \mathbf{e}$ bearing the EDG group of triphenylamine, $\mathbf{2 h}$ also gave a good yield of $\mathbf{3 h} \mathbf{\mathbf { h }}(\mathbf{7 6} \%$, Table 1 , entry 8$)$. These results indicate that an increase of the electron donating character of the substituted aryl groups leads to a higher nucleophilicity of the aryllithium reagents and thereby promotes the process of a ring-opening reaction. On the other hand, in the case of $\mathbf{2 d}$, which has a cyano group, a poor yield of $\mathbf{3 d}(42 \%$, Table 1, entry 4) was obtained due to the high stability of cyano-aryl anion with a low nucleophilicity.

The steric hinderance effect can be observed in the case of 2a, $2 \mathbf{f}$ and $\mathbf{2 g}$ (Table 1, entries 1, 6 and 7). When the bulkiness of aryl groups increased from benzene to anthracene, the yields of ring-opening products decreased from $\mathbf{3 a}(88 \%)$, to $\mathbf{3 f}(61 \%)$ and to $3 \mathrm{~g}(56 \%)$. Therefore, the aryllithium reagents with bulky groups, such as anthryllithium, generate lower yields of ringopening products than phenyllithium as the nucleophilic reagent.

An interesting result was observed for the metal-halogen exchange of 1 -bromopyrene (2i) with $n$-BuLi or $t$-BuLi at $-78{ }^{\circ} \mathrm{C}$, which delivered different types of ring-opening products (Scheme 2). When $n$-BuLi was used for the metal-halogen exchange, the reaction temperature was set at $0{ }^{\circ} \mathrm{C}$ for the ringopening reaction of 1 for $3 \mathrm{~h}$. Instead of the expected product, however, an unexpected ring-opening product 2'-butyl-5,5'dioctyl-2-(1-pyrenylthio)-3,3'-bithiophene (4, 45\%) along with 1-pyrenecarboxaldehyde $(\mathbf{5}, 35 \%)$ was generated when the reaction mixture was quenched with dry DMF. If $t$-BuLi was employed for the metal-halogen exchange, only anticipated product $3 \mathbf{i}$ was obtained in $48 \%$ yield and no 4 was observed. The structure of $\mathbf{3 i}$ was confirmed by a single-crystal structure analysis (Figure 1). 
Table 1: The ring opening of 2,5-dioctyldithieno[2,3-b:3',2'-d]thiophene (1) with aryllithium reagents $2 a-\mathbf{i}$.

$$
\underset{2}{\mathrm{Ar}-\mathrm{Br}} \stackrel{n-\mathrm{BuLi}}{\longrightarrow} \mathrm{Ar}-\mathrm{Li} \text { (Base) }
$$

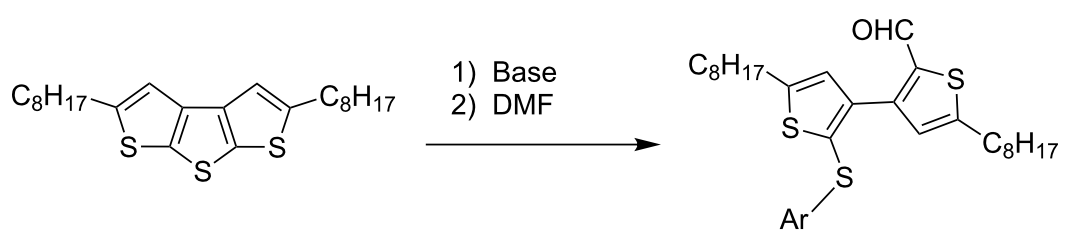

1

3

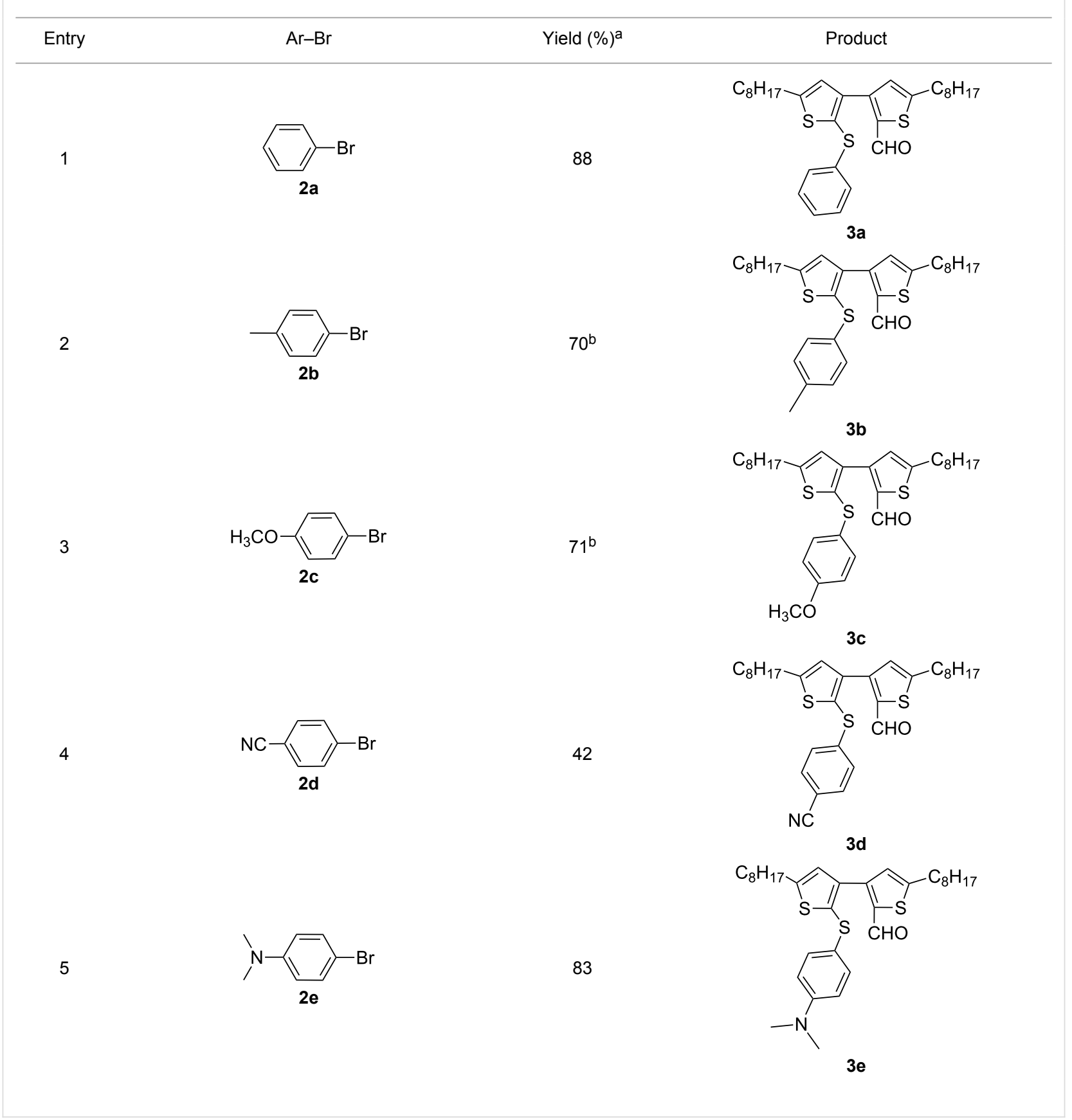


Table 1: The ring opening of 2,5-dioctyldithieno[2,3-b:3',2'- $d]$ thiophene (1) with aryllithium reagents $2 a-i$. (continued)

6

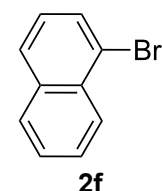

7

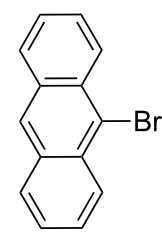

2g<smiles>Brc1ccc(N(c2ccccc2)c2ccccc2)cc1</smiles>

$2 \mathrm{~h}$

9

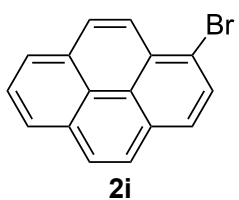

61<smiles>O=Cc1sc([18F])cc1-c1cc([18F])sc1Sc1cccc2ccccc12</smiles>

$3 \mathbf{f}$

56<smiles>[13CH2]c1cc(-c2cc(C([18F])c3ccccc3)sc2C=O)c(Sc2c3ccccc3cc3ccccc23)s1</smiles>

$3 \mathrm{~g}$<smiles>[CH+]c1cc(-c2cc([18F])sc2C=O)c(Sc2ccc(N(c3ccccc3)c3ccccc3)cc2)s1</smiles>

$3 h$

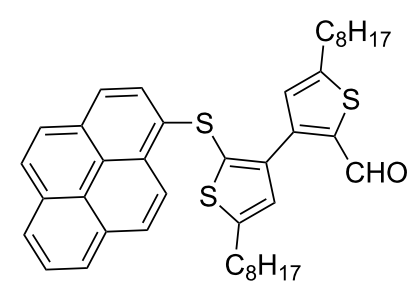

$3 \mathbf{i}$

aYield of the isolated product. ${ }^{\mathrm{b}} n$-BuLi was added at $-78^{\circ} \mathrm{C}$ then warmed up to $-30^{\circ} \mathrm{C}$ for $3 \mathrm{~h}$. ${ }^{\mathrm{C}} t$-BuLi was employed instead of $n$-BuLi.

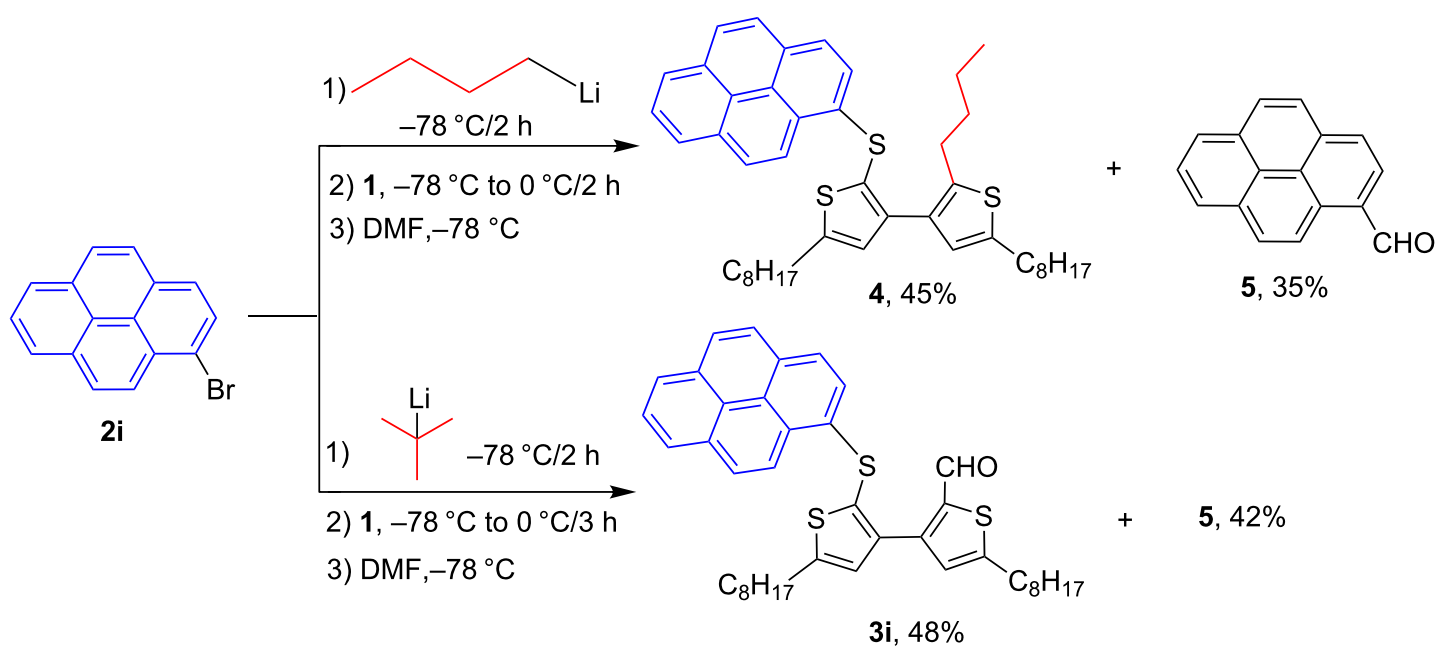

Scheme 2: The ring-opening reaction of 1 in the presence of $n$-BuLi and $t$-BuLi employed for metal-halogen exchange. 


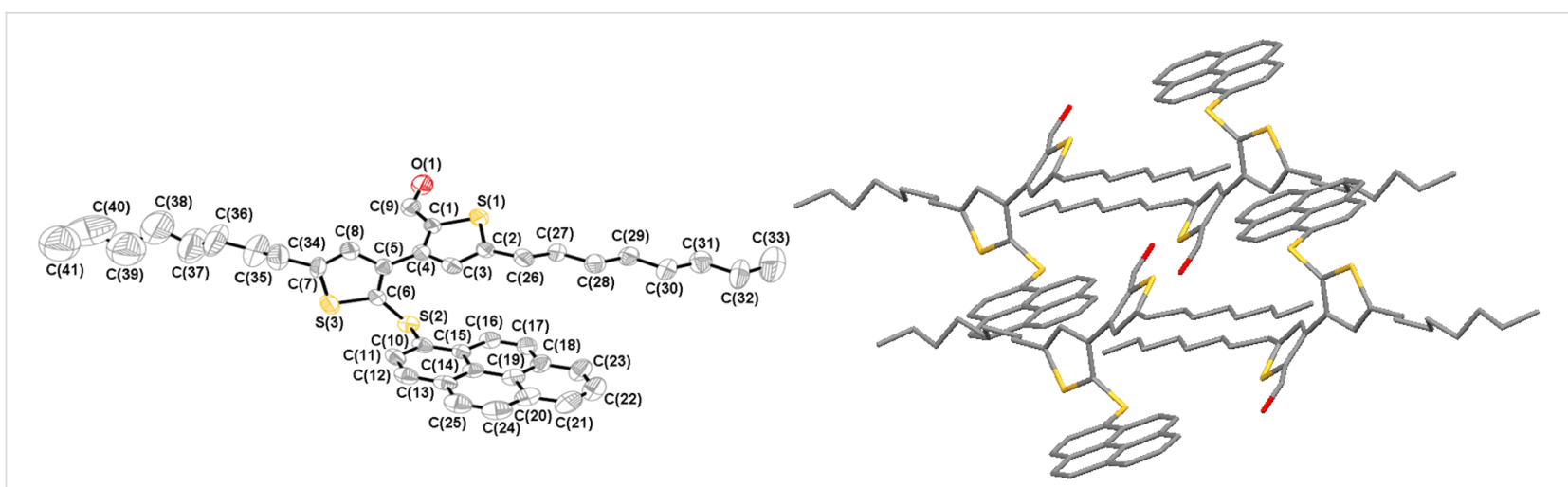

Figure 1: Crystallographic structure of $\mathbf{3 i}$ (left, top view) and crystal packing (right). Carbon, silicon, oxygen and sulfur atoms are depicted with thermal ellipsoids set at $50 \%$ probability level, and all hydrogen atoms are omitted for clarity.

In our work, the metal-halogen exchange of 1-bromopyrene (2i) with $n$-BuLi or $t$-BuLi at $-78{ }^{\circ} \mathrm{C}$ delivered different types of ring-opening products. We believe that the two metal-halogen exchange processes went to complete conversion. The formation of $\mathbf{4}$ is possibly due to the in situ generation of $n$ - $\mathrm{BuBr}$ that is trapped by the carbanion generated from an attack of pyrenyllithium (PyLi) on the central sulfur atom of 1. The presence of the pyrene carbanion intermediate is responsible for the formation of $\mathbf{5}$ by dry DMF quenching. However, if $t$-BuLi was used for the metal-halogen exchange, $t$-BuBr could not be efficiently generated due to the fast elimination occurring between the formed $t-\mathrm{BuBr}$ and another equivalent of $t$-BuLi. The formed pyrene-Li attacks the sulfur center of $\mathbf{1}$ and generates the carbanion intermediate via a ring-opening mechanism, which was quenched only by dry DMF, resulting in $\mathbf{3 i}$.

\section{Crystal structure of 2'-(1-pyrenylsulfanyl)- 5,5'-dioctyl-[3,3'-bithiophene]-2-carbalde- hyde (3i)}

The crystallographic structure of $\mathbf{3 i}$ is shown in Figure 1 [15]. The crystal of $\mathbf{3 i}$ belongs to the triclinic space group $\mathrm{P}-1$. The two thiophene rings are linked together in the molecule with a torsional angle (C3-C4-C5-C6) of 55.4 ${ }^{\circ}$ and a dihedral angle of $56.1^{\circ}$. The pyrenylsulfanyl group is not coplanar to the neighboring thiophene ring with a dihedral angle of $79.5^{\circ}$ and a torsion angle (C5-C6-S2-C10) of 89.7 ${ }^{\circ}$. There are short contacts of hydrogen bonding found in the crystal packing. However, no $\pi-\pi$ interaction was observed between two pyrene rings, as usually seen in the crystal (Figure 1, right).

\section{Conclusion}

In summary, aryllithium reagents are suitable for the ring opening of 2,5-dioctyldithieno[2,3-b:3',2'-d]thiophene. We obtained nine ring-opening products. Their yields indicated that strong nucleophilicity of the aryllithium reagents can intensify the efficiency of the ring-opening process, and the steric effect is another factor that could influence the yield. This ring opening can be applied extensively to derivatives including 2'-arylthio-3,3'-dithiophenyl-2-aldehydes, which may provide access to a broad range of compounds for pharmaceutical chemistry, organic chemistry and materials science.

\section{Experimental}

Synthesis of 2 '-phenylsulfanyl-5,5'-dioctyl-[3,3'bithiophene]-2-carbaldehyde (3a): To a solution of $\mathbf{2 a}$ (49.7 mg, $0.32 \mathrm{mmol}, 1.4$ equiv) in dry THF (10 mL), $n$-BuLi (2.38 $\mathrm{M}$ in hexane, $0.12 \mathrm{~mL}, 0.29 \mathrm{mmol}, 1.3$ equiv) was added dropwise at $-78^{\circ} \mathrm{C}$. After stirring at $-78^{\circ} \mathrm{C}$ for $2 \mathrm{~h}$, a solution of 1 (95.0 mg, $0.23 \mathrm{mmol}, 1.0$ equiv) in dry THF (10 mL) was added dropwise. The mixture was slowly warmed to $-30{ }^{\circ} \mathrm{C}$ for $3 \mathrm{~h}$, then dry DMF ( $0.04 \mathrm{~mL}, 0.45 \mathrm{mmol}, 2.0$ equiv) was added dropwise at $-78{ }^{\circ} \mathrm{C}$, and the reaction mixture was slowly warmed to ambient temperature overnight. After quenching with $\mathrm{H}_{2} \mathrm{O}(30 \mathrm{~mL})$, the reaction mixture was extracted with $\mathrm{CHCl}_{3}(2 \times 30 \mathrm{~mL})$ and then washed with $\mathrm{H}_{2} \mathrm{O}(30 \mathrm{~mL})$. After drying over $\mathrm{MgSO}_{4}$, the solvent was removed in vacuum. The residue was purified by column chromatography on silica gel with petrol ether $\left(60-90{ }^{\circ} \mathrm{C}\right) /$ chloroform $(1: 4, \mathrm{v} / \mathrm{v})$ as eluents to yield 3a (105.1 mg, 88.4\%) as a light yellow oil. ${ }^{1} \mathrm{H}$ NMR $\left(400 \mathrm{MHz}, \mathrm{CDCl}_{3}\right) \delta 9.70(\mathrm{~s}, 1 \mathrm{H}), 7.22-7.19(\mathrm{~m}, 2 \mathrm{H})$, $7.14-7.07(\mathrm{~m}, 3 \mathrm{H}), 6.87(\mathrm{~s}, 1 \mathrm{H}), 6.82(\mathrm{~s}, 1 \mathrm{H}), 2.82(\mathrm{t}, J=7.6$ $\mathrm{Hz}, 2 \mathrm{H}), 2.79$ (d, $J=7.4 \mathrm{~Hz}, 2 \mathrm{H}), 1.74-1.61$ (m, 4H), 1.40-1.27 $(\mathrm{m}, 20 \mathrm{H}), 0.90-0.87(\mathrm{~m}, 6 \mathrm{H}) ;{ }^{13} \mathrm{C} \mathrm{NMR}\left(100 \mathrm{MHz} \mathrm{CDCl}_{3}\right) \delta$ 183.03, 155.28, 150.54, 144.49, 139.86, 137.93, 136.87, 128.83, $128.30,127.74,127.16,126.06,126.02,31.71,31.12,30.85$, 30.56, 30.31, 29.14, 29.11, 29.06, 29.04, 28.98, 28.82, 22.54, 14.01; IR (KBr): 2955, 2926, $2855(\mathrm{C}-\mathrm{H}), 1661(\mathrm{C}=\mathrm{O}) \mathrm{cm}^{-1}$; HRMS-EI $m / z$ : $\left[\mathrm{M}^{+}+\mathrm{Na}\right]$ calcd for $\mathrm{C}_{31} \mathrm{H}_{42} \mathrm{OS}_{3} \mathrm{Na}, 549.2293$; found, 549.2290.

Synthesis of 2'-(4-methylphenylsulfanyl)-5,5'-dioctyl-[3,3'bithiophene]-2-carbaldehyde (3b): The same procedure was 
used as for the synthesis of $\mathbf{3 a}$ except that after the addition of $n$ - $\mathrm{BuLi}$, the reaction temperature was raised to $-30{ }^{\circ} \mathrm{C}$ for $3 \mathrm{~h}$, and then cooled back to $-78{ }^{\circ} \mathrm{C}$ before the addition of 1 . From the reaction on the $54.2 \mathrm{mg}$ scale of $\mathbf{2 b}, 90.0 \mathrm{mg}(70.3 \%)$ of $\mathbf{3 b}$ was obtained as a yellow oil. ${ }^{1} \mathrm{H} \mathrm{NMR}\left(400 \mathrm{MHz}, \mathrm{CDCl}_{3}\right) \delta$ $9.69(\mathrm{~s}, 1 \mathrm{H}), 7.02(\mathrm{~s}, 4 \mathrm{H}), 6.84(\mathrm{~d}, J=1.3 \mathrm{~Hz}, 2 \mathrm{H}), 2.80$ (t, $J=$ $7.2 \mathrm{~Hz}, 2 \mathrm{H}), 2.79$ (t, $J=7.2 \mathrm{~Hz}, 2 \mathrm{H}), 2.28(\mathrm{~s}, 3 \mathrm{H}), 1.73-1.63$ $(\mathrm{m}, 4 \mathrm{H}), 1.39-1.28(\mathrm{~m}, 20 \mathrm{H}), 0.88(\mathrm{t}, J=6.8 \mathrm{~Hz}, 6 \mathrm{H})$; ${ }^{13} \mathrm{C}$ NMR $\left(100 \mathrm{MHz}, \mathrm{CDCl}_{3}\right) \delta 183.28,155.38,150.07,144.78$, 139.14, 136.86, 136.41, 134.09, 129.70, 128.44, 128.13, 127.65, $127.42,31.77,31.18,30.96,30.66,30.35,29.20,29.19,29.12$, 29.04, 28.92, 22.60, 20.92, 14.07; IR (KBr): 2956, 2926, 2855 $(\mathrm{C}-\mathrm{H}), 1661(\mathrm{C}=\mathrm{O}) \mathrm{cm}^{-1}$; HRMS-EI $m / z$ : $\left[\mathrm{M}^{+}+\mathrm{Na}\right]$ calcd for $\mathrm{C}_{32} \mathrm{H}_{44} \mathrm{OS}_{3} \mathrm{Na}$, 563.2430; found, 563.2437.

Synthesis of 2'-(4-methoxylphenylsulfanyl)-5,5'-dioctyl-[3,3'bithiophene]-2-carbaldehyde (3c): The same procedure was used as for the synthesis of $\mathbf{3 b}$. From the reaction on the $61.9 \mathrm{mg}$ scale of $\mathbf{2 c}, 92.9 \mathrm{mg}(70.5 \%)$ of $\mathbf{3 c}$ was obtained as a yellow oil. ${ }^{1} \mathrm{H}$ NMR $\left(400 \mathrm{MHz}, \mathrm{CDCl}_{3}\right) \delta 9.68(\mathrm{~s}, 1 \mathrm{H})$, 7.13-7.10 (m, 2H), $6.85(\mathrm{~s}, 1 \mathrm{H}), 6.78(\mathrm{~s}, 1 \mathrm{H}), 6.77-6.74(\mathrm{~m}$, 2H), $3.75(\mathrm{~s}, 3 \mathrm{H}), 2.82(\mathrm{t}, J=7.6 \mathrm{~Hz}, 2 \mathrm{H}), 2.76(\mathrm{t}, J=7.7 \mathrm{~Hz}$, $2 \mathrm{H}), 1.73-1.63(\mathrm{~m}, 4 \mathrm{H}), 1.37-1.27(\mathrm{~m}, 20 \mathrm{H}), 0.90-0.86(\mathrm{~m}$, $6 \mathrm{H}) ;{ }^{13} \mathrm{C}$ NMR $\left(100 \mathrm{MHz}, \mathrm{CDCl}_{3}\right) \delta 183.34,158.98,155.41$, 149.24, 144.91, 137.82, 136.78, 131.34, 129.42, 128.46, 127.50, $127.47,114.57,55.21,31.76,31.17,31,02,30.68,30,29,29.19$, 29.11, 29.03, 28.94, 22.59, 14.06; IR (KBr): 2958, 2926, 2856 (C-H), $1661(\mathrm{C}=\mathrm{O}) \mathrm{cm}^{-1}$; HRMS-EI $m / z$ : $\left[\mathrm{M}^{+}+\mathrm{Na}\right]$ calcd for $\mathrm{C}_{32} \mathrm{H}_{44} \mathrm{O}_{2} \mathrm{~S}_{3} \mathrm{Na}$, 579.2395; found, 579.2396.

Synthesis of 2'-(4-cyanolphenylsulfanyl)-5,5'-dioctyl-[3,3'bithiophene]-2-carbaldehyde (3d): The same procedure was used as for the synthesis of $\mathbf{3 a}$. From the reaction on the $60.2 \mathrm{mg}$ scale of $\mathbf{2 d}, 54.9 \mathrm{mg}(42.1 \%)$ of $\mathbf{3 d}$ was obtained as a yellow oil. ${ }^{1} \mathrm{H}$ NMR $\left(400 \mathrm{MHz}, \mathrm{CDCl}_{3}\right) \delta 9.69(\mathrm{~s}, 1 \mathrm{H}), 7.46(\mathrm{~d}$, $J=7.3 \mathrm{~Hz}, 2 \mathrm{H}), 7.05$ (d, $J=7.3 \mathrm{~Hz}, 2 \mathrm{H}), 6.94(\mathrm{~s}, 1 \mathrm{H}), 6.73$ (s, $1 \mathrm{H}), 2.85(\mathrm{t}, J=7.6 \mathrm{~Hz}, 2 \mathrm{H}), 2.77(\mathrm{t}, J=7.5 \mathrm{~Hz}, 2 \mathrm{H}), 1.75-1.58$ $(\mathrm{m}, 4 \mathrm{H}), 1.40-1.24(\mathrm{~m}, 20 \mathrm{H}), 0.89-0.86(\mathrm{~m}, 6 \mathrm{H}) ;{ }^{13} \mathrm{C} \mathrm{NMR}$ $\left(100 \mathrm{MHz}, \mathrm{CDCl}_{3}\right) \delta 182.81,155.90,152.59,145.75,143.64$, $141.81,137.13,132.37,128.18,127.94,125.80,121.97,118.53$, $108.94,31.77,31.75,31.17,30.95,30.64,30.49,29.19,29.15$, 29.12, 29.10, 29.06, 28.96, 28.88, 22.60, 14.07; IR (KBr): 2956, 2926, $2856(\mathrm{C}-\mathrm{H}), 2228(\mathrm{C} \equiv \mathrm{N}), 1661(\mathrm{C}=\mathrm{O}) \mathrm{cm}^{-1}$; HRMS-EI $m / z:\left[\mathrm{M}^{+}+\mathrm{Na}\right]$ calcd for $\mathrm{C}_{32} \mathrm{H}_{41} \mathrm{NOS}_{3} \mathrm{Na}, 574.2244$; found, 574.2243 .

Synthesis of 2'-[4-( $\mathrm{N}, \mathrm{N}$-dimethylamino)phenylsulfanyl]-5,5'dioctyl-[3,3'-bithiophene]-2-carbaldehyde (3e): The same procedure was used as for the synthesis of 3a. From the reaction on the $66.3 \mathrm{mg}$ scale of $\mathbf{2 e}, 112.2 \mathrm{mg}(83.2 \%)$ of $\mathbf{3 e}$ was obtained as a yellow oil. ${ }^{1} \mathrm{H} \mathrm{NMR}\left(400 \mathrm{MHz}, \mathrm{CDCl}_{3}\right) \delta 9.72(\mathrm{~s}$,
$1 \mathrm{H}), 7.16-7.14(\mathrm{~m}, 2 \mathrm{H}), 6.92(\mathrm{~s}, 1 \mathrm{H}), 6.74(\mathrm{~s}, 1 \mathrm{H}), 6.59-6.56$ $(\mathrm{m}, 2 \mathrm{H}), 2.93(\mathrm{~s}, 6 \mathrm{H}), 2.85(\mathrm{t}, J=7.6 \mathrm{~Hz}, 2 \mathrm{H}), 2.73(\mathrm{t}, J=7.7$ $\mathrm{Hz}, 2 \mathrm{H}$ ), 1.72 (quint, $J=6.5 \mathrm{~Hz}, 2 \mathrm{H}$ ), 1.65 (quint, $J=7.6 \mathrm{~Hz}$, $2 \mathrm{H}), 1.41-1.28(\mathrm{~m}, 20 \mathrm{H}), 0.89$ (t, $J=10.8 \mathrm{~Hz}, 6 \mathrm{H}) ;{ }^{13} \mathrm{C} \mathrm{NMR}$ $\left(100 \mathrm{MHz}, \mathrm{CDCl}_{3}\right) \delta 183.48,155.26,150.00,147.86,145.27$, $136.60,135.78,132.82,132.29,128.57,127.25,120.98,112.59$, $40.17,31.74,31.73,31.16,31.01,30.68,30.20,29.18,29.16$, 29.09, 29.07, 29.01, 28.94, 22.56, 14.02; IR (KBr): 2954, 2924, $2851(\mathrm{C}-\mathrm{H}), 1659(\mathrm{C}=\mathrm{O}) \mathrm{cm}^{-1}$; HRMS-EI $m / z$ : $\left[\mathrm{M}^{+}+\mathrm{Na}\right]$ calcd for $\mathrm{C}_{33} \mathrm{H}_{47} \mathrm{NOS}_{3} \mathrm{Na}, 592.2709$; found, 592.2712.

Synthesis of 2'-(1-naphthylsulfanyl)-5,5'-dioctyl-[3,3'-bithiophene]-2-carbaldehyde (3f): The same procedure was used as for the synthesis of $\mathbf{3 a}$. From the reaction on the $72.4 \mathrm{mg}$ scale of $\mathbf{2 f}, 84.7 \mathrm{mg}(60.5 \%)$ of $\mathbf{3 f}$ was obtained as a yellow oil. ${ }^{1} \mathrm{H}$ NMR $\left(400 \mathrm{MHz}, \mathrm{CDCl}_{3}\right) \delta 9.76(\mathrm{~s}, 1 \mathrm{H}), 8.22-8.19(\mathrm{~m}, 1 \mathrm{H})$, $7.84-7.82(\mathrm{~m}, 1 \mathrm{H}), 7.71(\mathrm{~d}, J=8.2 \mathrm{~Hz}, 1 \mathrm{H}), 7.51-7.49(\mathrm{~m}, 2 \mathrm{H})$, $7.34(\mathrm{t}, J=7.56 \mathrm{~Hz}, 1 \mathrm{H}), 7.25(\mathrm{~d}, J=7.21 \mathrm{~Hz}, 1 \mathrm{H}), 6.87(\mathrm{~s}$, $1 \mathrm{H}), 6.84(\mathrm{~s}, 1 \mathrm{H}), 2.81(\mathrm{t}, J=7.6 \mathrm{~Hz}, 2 \mathrm{H}), 2.75(\mathrm{t}, J=7.5 \mathrm{~Hz}$, $2 \mathrm{H}$ ), 1.70 (quint, $J=7.3 \mathrm{~Hz}, 2 \mathrm{H}$ ), 1.59 (quint, $J=7.6 \mathrm{~Hz}, 2 \mathrm{H}$ ), $1.39-1.25(\mathrm{~m}, 22 \mathrm{H}), 0.90(\mathrm{t}, J=5.8 \mathrm{~Hz}, 6 \mathrm{H}) ;{ }^{13} \mathrm{C} \mathrm{NMR}$ $\left(100 \mathrm{MHz}, \mathrm{CDCl}_{3}\right) \delta 183.23,155.54,150.30,144.76,139.41$, $136.91,134.74,133.70,131.40,128.35,128.34,127.71,127.42$, $127.12,126.73,126.39,126.26,125.56,124.25,31.76,31.16$, $30.85,30.60,30.36,29.19,29.12,29.06,29.04,28.88,22.60$, 14.08; IR (KBr): 2956, 2926, $2855(\mathrm{C}-\mathrm{H}), 1661(\mathrm{C}=\mathrm{O}) \mathrm{cm}^{-1}$; HRMS-EI $m / z$ : $\left[\mathrm{M}^{+}+\mathrm{Na}\right]$ calcd for $\mathrm{C}_{35} \mathrm{H}_{44} \mathrm{OS}_{3} \mathrm{Na}, 599.2443$; found, 599.2447.

Synthesis of 2'-(9-anthrylsulfanyl)-5,5'-dioctyl-[3,3'-bithiophene]-2-carbaldehyde (3g): The same procedure was used as for the synthesis of $\mathbf{3 a}$. From the reaction on the $87.4 \mathrm{mg}$ scale of $2 \mathrm{~g}, 85.8 \mathrm{mg}$ (56.4\%) of $\mathbf{3 g}$ was obtained as a yellow oil. ${ }^{1} \mathrm{H}$ NMR $\left(400 \mathrm{MHz}, \mathrm{CDCl}_{3}\right) \delta 9.60(\mathrm{~s}, 1 \mathrm{H}), 8.62(\mathrm{~d}, J=9.4 \mathrm{~Hz}$, $2 \mathrm{H}), 8.47$ (s, 1H), $7.98(\mathrm{~d}, J=9.1 \mathrm{~Hz}, 2 \mathrm{H}), 7.51-7.45(\mathrm{~m}, 4 \mathrm{H})$, $6.91(\mathrm{~s}, 1 \mathrm{H}), 6.60(\mathrm{~s}, 1 \mathrm{H}), 2.85(\mathrm{t}, J=7.6 \mathrm{~Hz}, 2 \mathrm{H}), 2.54(\mathrm{t}, J=$ $7.7 \mathrm{~Hz}, 2 \mathrm{H}), 1.75$ (quint, $J=3.0 \mathrm{~Hz}, 2 \mathrm{H}), 1.48-1.20(\mathrm{~m}, 22 \mathrm{H})$, $0.89(\mathrm{dd}, J=6.4 \mathrm{~Hz}, 12.8 \mathrm{~Hz}, 6 \mathrm{H}) ;{ }^{13} \mathrm{C} \mathrm{NMR}(100 \mathrm{MHz}$, $\left.\mathrm{CDCl}_{3}\right) \delta 183.32,155.58,147.19,145.39,137.02,135.14$, 134.08, 133.82, 132.41, 131.76, 130.06, 128.82, 128.76, 128.14, $127.18,126.94,126.57,125.41,31.82,31.74,31.09,31.06$, $30.77,30.10,29.68,29.27,29.18,29.13,29.09,20.08,28.99$, 22.63, 22.58, 14.07, 14.06; IR (KBr): 2956, 2926, 2856 (C-H), $1649(\mathrm{C}=\mathrm{O}) \mathrm{cm}^{-1}$; HRMS-EI $\mathrm{m} / z:\left[\mathrm{M}^{+}+\mathrm{Na}\right]$ calcd for $\mathrm{C}_{39} \mathrm{H}_{46} \mathrm{OSS}_{3} \mathrm{Na}, 649.2613$; found, 649.2603.

Synthesis of 2'-[4-( $N, N$-diphenylamino)phenylsulfanyl $]-5,5 '-$ dioctyl-[3,3'-bithiophene]-2-carbaldehyde (3h): The same procedure was used as for the synthesis of 3a. From the reaction on the $100.1 \mathrm{mg}$ scale of $\mathbf{2 h}, 127.4 \mathrm{mg}(75.6 \%)$ of $\mathbf{3 h}$ was obtained as a yellow oil. ${ }^{1} \mathrm{H}$ NMR $\left(400 \mathrm{MHz}, \mathrm{CDCl}_{3}\right) \delta 9.65(\mathrm{~s}$, 
1H), 7.26-7.22 (m, 3H), 7.06-7.02 (m, 6H), 7.00-6.99 (m, 1H), 6.98-6.97 (m, 2H), 6.91-6.88 (m, 2H) $6.88(\mathrm{~s}, 1 \mathrm{H}), 6.81(\mathrm{~s}$, $1 \mathrm{H}), 2.85-2.77(\mathrm{~m}, 4 \mathrm{H}), 1.73-1.65(\mathrm{~m}, 4 \mathrm{H}), 1.39-1.26(\mathrm{~m}$, $20 \mathrm{H}), 0.90(\mathrm{td}, J=6.4 \mathrm{~Hz}, 3.2 \mathrm{~Hz}, 6 \mathrm{H}) ;{ }^{13} \mathrm{C} \mathrm{NMR}(100 \mathrm{MHz}$, $\left.\mathrm{CDCl}_{3}\right) \delta 183.28,155.41,149.67,147.28,146.82,144.92$, $138.63,136.89,129.94,129.55,129.25,128.50,128.27,127.69$, $124.47,123.63,123.12,31.80,31.78,31.23,31.04,30.75$, $30.36,29.23,29.21,29.14,29.09,29.00,22.62,14.10$. IR (KBr): 2956, 2926, $2855(\mathrm{C}-\mathrm{H}), 1661(\mathrm{C}=\mathrm{O}) \mathrm{cm}^{-1}$; HRMS-EI $m / z:\left[\mathrm{M}^{+}+\mathrm{Na}\right]$ calcd for $\mathrm{C}_{43} \mathrm{H}_{51} \mathrm{NOS}_{3} \mathrm{Na}, 716.3037$; found, 716.3025 .

Synthesis of 2'-(1-pyrenylsulfanyl)-5,5'-dioctyl-[3,3'-bithiophene]-2-carbaldehyde (3i): The same procedure was used as for the synthesis of $\mathbf{3 a}$ except for two differences. One is that $t$-BuLi (2.6 equiv) was employed for the metal-halogen exchange, and another one is that the temperature for the ringopening reaction of $\mathbf{1}$ was set to $0{ }^{\circ} \mathrm{C}$ for $3 \mathrm{~h}$. From the reaction on the $87.7 \mathrm{mg}$ (1.4 equiv) scale of $\mathbf{2 i}, 69.1 \mathrm{mg}(47.7 \%)$ of $\mathbf{3 i}$ and a side product, 1-pyrenecarboxaldehyde $(27.8 \mathrm{mg}, 42.0 \%)$ were generated. $3 \mathbf{i}$ was obtained as a light yellow solid, $\mathrm{mp}$ 66-68 ${ }^{\circ} \mathrm{C} ;{ }^{1} \mathrm{H}$ NMR $\left(400 \mathrm{MHz}, \mathrm{CDCl}_{3}\right) \delta 9.79(\mathrm{~s}, 1 \mathrm{H}), 8.43(\mathrm{~d}$, $J=9.2 \mathrm{~Hz}, 1 \mathrm{H}), 8.18-8.16(\mathrm{~m}, 2 \mathrm{H}), 8.08-7.95(\mathrm{~m}, 5 \mathrm{H}), 7.80$ (d, $J=8.1 \mathrm{~Hz}, 1 \mathrm{H}), 6.84(\mathrm{~s}, 1 \mathrm{H}), 6.75(\mathrm{~s}, 1 \mathrm{H}), 2.77(\mathrm{t}, J=7.6 \mathrm{~Hz}$, $2 \mathrm{H}), 2.63(\mathrm{t}, J=7.6 \mathrm{~Hz}, 2 \mathrm{H}), 1.70-1.63(\mathrm{~m}, 2 \mathrm{H}), 1.47-1.13(\mathrm{~m}$, $22 \mathrm{H}), 0.88(\mathrm{t}, J=6.8 \mathrm{~Hz}, 3 \mathrm{H}), 0.85(\mathrm{t}, J=7.0 \mathrm{~Hz}, 3 \mathrm{H})$; ${ }^{13} \mathrm{C} \mathrm{NMR}\left(100 \mathrm{MHz}, \mathrm{CDCl}_{3}\right) \delta 183.27,155.54,149.92,144.82$, 138.90, 136.93, 131.40, 131.15, 130.71, 130.36, 129.58, 128.27, $128.12,127.92,127.62,127.54,127.00,126.12,125.36,125.28$, $124.94,124.86,124.18,123.54,31.75,31.70,31.15,30,74$, $30.52,30.34,29.17,29.10,29.03,29.01,28.84,22.59,22.55$, 14.06, 14.04; IR (KBr): 2956, 2926, 2854 (C-H), 1653 (C=O) $\mathrm{cm}^{-1}$; HRMS-EI $\mathrm{m} / z$ : $\left[\mathrm{M}^{+}+\mathrm{Na}\right]$ calcd for $\mathrm{C}_{41} \mathrm{H}_{46} \mathrm{OS}_{3} \mathrm{Na}$, 673.2611; found, 673.2603 .

Synthesis of 2-butyl-2'-(1-pyrenylsulfanyl)-5,5'-dioctyl-3,3'bithiophene (4): To a solution of $2 \mathbf{i}(93.7 \mathrm{mg}, 0.33 \mathrm{mmol}$, 1.4 equiv) in dry THF $(10 \mathrm{~mL}), n$-BuLi $(2.39 \mathrm{M}$ in hexane, $0.13 \mathrm{~mL}, 0.31 \mathrm{mmol}, 1.3$ equiv) was added dropwise at $-78^{\circ} \mathrm{C}$. After slowly warming to $-78{ }^{\circ} \mathrm{C}$ for $2 \mathrm{~h}$, a solution of $\mathbf{1}$ (100.1 mg, $0.24 \mathrm{mmol}, 1.0$ equiv) in dry THF $(10 \mathrm{~mL})$ was added dropwise. The reaction mixture was slowly warmed to $0{ }^{\circ} \mathrm{C}$ for $3 \mathrm{~h}$, then cooled back to $-78^{\circ} \mathrm{C}$. Dry DMF $(0.05 \mathrm{~mL}$, $0.48 \mathrm{mmol}, 2.0$ equiv) was added dropwise, and the reaction mixture was slowly warmed to ambient temperature overnight. After quenching with $\mathrm{H}_{2} \mathrm{O}(30 \mathrm{~mL})$, the reaction mixture was extracted with $\mathrm{CHCl}_{3}(2 \times 30 \mathrm{~mL})$ and then washed with $\mathrm{H}_{2} \mathrm{O}$ $(30 \mathrm{~mL})$. After drying over $\mathrm{MgSO}_{4}$, the solvent was removed in vacuum. The residue was purified by column chromatography on silica gel with petrol ether $\left(60-90^{\circ} \mathrm{C}\right) /$ chloroform $(1: 4, \mathrm{v} / \mathrm{v})$ as eluents, $72.6 \mathrm{mg}(45 \%)$ of 4 was obtained as a brown oil, and
$5(24.5 \mathrm{mg}, 35 \%)$ was also obtained. For 4, ${ }^{1} \mathrm{H}$ NMR $\left(400 \mathrm{MHz}, \mathrm{CDCl}_{3}\right) \delta 8.49(\mathrm{~d}, J=9.2 \mathrm{~Hz}, 1 \mathrm{H}), 8.18-8.15$ (dd, $J$ $=3.6,7.7 \mathrm{~Hz}, 2 \mathrm{H}), 8.07(\mathrm{~d}, 1 \mathrm{H}), 8.04-7.95(\mathrm{~m}, 4 \mathrm{H}), 7.80(\mathrm{~d}, J=$ $8.1 \mathrm{~Hz}, 1 \mathrm{H}), 6.77(\mathrm{~s}, 1 \mathrm{H}), 6.58(\mathrm{~s}, 1 \mathrm{H}), 2.78(\mathrm{t}, J=7.5 \mathrm{~Hz}, 2 \mathrm{H})$, $2.69(\mathrm{t}, J=7.5 \mathrm{~Hz}, 2 \mathrm{H}), 2.60(\mathrm{t}, J=7.6 \mathrm{~Hz}, 2 \mathrm{H}), 1.67$ (qt, $J=$ $7.4 \mathrm{~Hz}, 2 \mathrm{H}), 1.51-1.42(\mathrm{~m}, 4 \mathrm{H}), 1.32-1.10(\mathrm{~m}, 22 \mathrm{H}), 0.89(\mathrm{t}, J$ $=6.8 \mathrm{~Hz}, 3 \mathrm{H}), 0.85(\mathrm{t}, J=7.0 \mathrm{~Hz}, 3 \mathrm{H}), 0.80(\mathrm{t}, J=7.4 \mathrm{~Hz}, 3 \mathrm{H})$; ${ }^{13} \mathrm{C} \mathrm{NMR}\left(100 \mathrm{MHz}, \mathrm{CDCl}_{3}\right) \delta 149.28,143.27,141.10,139.92$, 133.08, 131.48, 131.34, 130.95, 129.96, 129.25, 127.62, 127.43, $127.36,127.21,126.07,126.02,125.16,125.11,124.95,124.55$, $124.45,123.89,34.04,31.83,31.81,31.27,31.22,30.53,29.92$, 29.71, 29.28, 29.21, 29.15, 29.06, 28.52, 22.66, 22.62, 22.39, 14.11, 13.79; IR (KBr): 3435 (Ar-H), 2956, 2924, 2855 (C-H) $\mathrm{cm}^{-1}$; HRMS-EI $\mathrm{m} / z$ : $[\mathrm{M}]^{+}$calcd for $\mathrm{C}_{44} \mathrm{H}_{54} \mathrm{~S}_{3}, 678.3392$; found, 678.3382 .

\section{Supporting Information}

\section{Supporting Information File 1}

Characterization data and NMR spectra of all compounds including the X-ray structure determination of $\mathbf{3 i}$. [http://www.beilstein-journals.org/bjoc/content/ supplementary/1860-5397-9-87-S1.pdf]

\section{Supporting Information File 2}

$\mathrm{X}$-ray crystallographic data file of $\mathbf{3 i}$.

[http://www.beilstein-journals.org/bjoc/content/

supplementary/1860-5397-9-87-S2.cif]

\section{Acknowledgements}

This research was supported by the National Natural Science Foundation of China (21270255, 51273055, 20972041, 50803015) and the Program for Innovation Scientists and Technicians Troop Construction Projects of Henan Province (104100510011).

\section{References}

1. Shi, J.; Xu, L.; Li, Y.; Jia, M.; Kan, Y.; Wang, H. Org. Electron. 2013, 14, 934-941. doi:10.1016/j.orgel.2013.01.002

2. Shi, J.; Li, Y.; Jia, M.; Xu, L.; Wang, H. J. Mater. Chem. 2011, 21, 17612-17614. doi:10.1039/c1jm14383b

3. Zhang, L.; Tan, L.; Wang, Z.; Hu, W.; Zhu, D. Chem. Mater. 2009, 21, 1993-1999. doi:10.1021/cm900369s

4. Tan, L.; Zhang, L.; Jiang, X.; Yang, X.; Wang, L.; Wang, Z.; Li, L.; Hu, W.; Shuai, Z.; Li, L.; Zhu, D. Adv. Funct. Mater. 2009, 19, 272-276. doi:10.1002/adfm.200800933

5. Wang, Z.; Zhao, C.; Zhao, D.; Li, C.; Zhang, J.; Wang, H. Tetrahedron 2010, 66, 2168-2174. doi:10.1016/j.tet.2010.01.056

6. Gronowitz, S.; Hallberg, A.; Frejd, T. Tetrahedron 1979, 35, 2607-2610. doi:10.1016/0040-4020(79)88028-X

7. Huang, H.; Li, J.; Lescop, C.; Duan, Z. Org. Lett. 2011, 13, 5252-5255. doi:10.1021/ol2021302 
8. Liang, Y.; Geng, W.; Wei, J.; Xi, Z. Angew. Chem., Int. Ed. 2012, 51, 1934-1937. doi:10.1002/anie.201108154

9. Wang, Y.; Chi, Y.; Zhang, W.-X.; Xi, Z. J. Am. Chem. Soc. 2012, 134, 2926-2929. doi:10.1021/ja211486f

10. Belley, M.; Douida, Z.; Mancuso, J.; De Vleeschauwer, M. Synlett 2005, 247-250. doi:10.1055/s-2004-837230

11. Hill, B.; De Vleeschauwer, M.; Houde, K.; Belley, M. Synlett 1998, 407-410. doi:10.1055/s-1998-1674

12. Dickinson, R. P.; Iddon, B. J. Chem. Soc. C 1971, 3447-3454. doi:10.1039/J39710003447

13. Fuller, L. S.; Iddon, B.; Smith, K. A. J. Chem. Soc., Perkin Trans. 1 1999, 1273-1278. doi:10.1039/a901300h

14. Chernichenko, K.; Emelyanov, N.; Gridnev, I.; Nenajdenko, V. G. Tetrahedron 2011, 67, 6812-6818. doi:10.1016/j.tet.2011.06.082

15. Crystal data for $3 \mathrm{i}: \mathrm{M}=650.96, \mathrm{C}_{41} \mathrm{H}_{46} \mathrm{OS}_{3}$, triclinic, space group $\mathrm{P}-1$, $a=9.395(2) \AA, b=11.384(2) \AA, c=18.540(3) \AA, \alpha=83.241(4)^{\circ}, \beta=$ $79.382(4)^{\circ}, \gamma=67.287(3)^{\circ}, V=1795.3(5) \AA^{3}, Z=2, D_{\text {calc }}=1.204$ $\mathrm{g} / \mathrm{cm}^{3}$. A colorless crystal of dimensions $0.44 \times 0.35 \times 0.11 \mathrm{~mm}$ was used for measurement at 296(2) K. The final cycle of full-matrix least-squares refinement was based on 6253 observed reflections $[I>2 \sigma(\mathrm{I})]$ and 380 variable parameters with $\mathrm{R}_{1}=0.0805, w \mathrm{R}_{2}=0.1802$.

\section{License and Terms}

This is an Open Access article under the terms of the Creative Commons Attribution License (http://creativecommons.org/licenses/by/2.0), which permits unrestricted use, distribution, and reproduction in any medium, provided the original work is properly cited.

The license is subject to the Beilstein Journal of Organic Chemistry terms and conditions:

(http://www.beilstein-journals.org/bjoc)

The definitive version of this article is the electronic one which can be found at: doi:10.3762/bjoc. 9.87 